\title{
Risk, Framing and Everyday Life: epistemological and methodological reflections from three sociocultural projects
}

*Karen Henwood, School of Social Sciences, Cardiff University

Nick Pidgeon, School of Psychology, Cardiff University

Sophie Sarre, Department of Social Policy, London School of Economics and Political Science

Peter Simmons, School of Environmental Sciences, University of East Anglia

Noel Smith, Centre for Research in Social Policy, Loughborough University

Short title: Risk, Framing and Everyday Life

*Corresponding author:

Karen Henwood

School of Social Sciences,

King Edward VII Ave,

Cardiff CF10 3WT

Email: HenwoodK@Cardiff.ac.uk

Acknowledgements: This paper emerged from our collective participation in the ESRC Priority Network on Social Contexts and Responses to Risk (SCARR). The original idea to write a collaborative paper on framing comparing data and interpretations across the three projects came from Sophie Sarre, who also orchestrated the paper. The research reported here and preparation of the article was supported by ESRC award RES-336-25-0001. Additional support to Nick Pidgeon 
came from a Leverhulme Trust award (F/00 407/AG). We wish to thank the following individuals: Peter Taylor-Gooby for encouraging this collaboration and for his efficient organisation of the SCARR network; Karen Parkhill for helpful discussions relating to the nuclear project; and Corinne Squire, Alan Irwin, Andy Alaszewski and one anonymous reviewer for insightful comments on an earlier version of this manuscript. 


\title{
Risk, Framing and Everyday Life: epistemological and methodological reflections from three sociocultural projects
}

\author{
Abstract \\ Multiplicity, variability and incongruity in the meanings of risk encountered \\ throughout the research process (and beyond) are key foci of inquiry within \\ sociocultural risk research, which attaches considerable importance to appreciating \\ participants' perspectives, orientations and contextual understandings. These foci are \\ also associated with epistemological and methodological dilemmas since in risk \\ research, as in social science more widely, researchers' theoretical assumptions and \\ problem formulations inevitably serve as key anchor points for the meanings that \\ come to be assigned to phenomena, events and situations under investigation. In this \\ article, we consider the idea of risk framing to explore how issues arising in \\ connection with variability in the meanings of 'risk' are dealt with in three different \\ sociocultural projects utilising a variety of forms of in-depth qualitative interview and \\ situated, contextual data analysis to investigate risks in: intimate relationships; \\ employment/career transitions; and nuclear hazards. The projects share the aim of \\ seeking to understand how risk perceptions play out in people's everyday life \\ situations in order to illuminate how people live with risk. The paper considers the \\ framing of risk at three stages of the research process - constructing the research \\ topic, presenting the research to participants, and interpreting meanings of data. A key \\ argument established through comparative analysis of these projects is that \\ consideration of risk framing is not only theoretically important but a key, reflexive \\ resource for risk researchers.
}


Risk, Framing and Everyday Life: epistemological and methodological reflections from three sociocultural projects

\section{Introduction}

Risk has become a focus for much contemporary research across the social sciences (Mythen and Walklate 2006; Taylor-Gooby and Zinn 2006). There are, however, significant differences in the way in which the concept of risk is defined and used, both across and within different disciplines (Pidgeon, Hood, Jones, Turner and Gibson, 1992; Lupton, 1999). It is perhaps no surprise, then, to find that in risk research, as in social science more generally, researchers' theoretical assumptions and problem formulations serve as key anchor points for the meanings that come to be assigned to the situations being investigated throughout the research process.

Importantly for the following discussion, one may differentiate between accounts which treat risk as an objectively given quality of a situation and those, notably from a sociocultural perspective, which assume that, whatever the ontological status of events which present hazards in the world, 'risk' cannot be reified in this way. Rather, what is perceived as risk and how that risk is perceived will vary according to the context in which, and from which, it is regarded ( $c f$. Douglas and Wildavsky, 1982;

Pidgeon, Kasperson and Slovic, 2003; Rosa, 2003).

In the current paper we utilise the ideas of framing and 'risk framing' to explore some of the epistemological and methodological dilemmas that such variability in meanings of the term 'risk' raise within the research encounter. We would argue that 
consideration of framing is not only theoretically important, but a key reflexive methodological resource for risk researchers. One reason for its importance is because there is a danger of researchers defining research situations from the outset in terms of some presumed universal notion of 'risk', thereby unreflexively importing to the research process a priori constructions of what that term might mean. Choice of topic, location, participants, etc. will also reflect the prior framing of the issue to be researched, as will decisions about how to present the research to potential participants, including how to respond to their queries. That presentation itself acts as a framing device for the research encounter, indicating what the researcher will be 'looking for' from the participant, what is 'relevant' and implicitly, or perhaps explicitly, what is not. Finally, when interpreting data, inferences are made about what constitutes, for example, an indicator of risk perception - what words, or conversely silences, are taken to indicate the presence of 'risk' in the minds and lives of participants?

In light of these considerations, this paper argues for a degree of self-reflexivity on the part of risk researchers, so that they are aware of their own framings, and remain sensitive to the possibilities and consequences of imposing them on research participants. It also highlights the ways in which participants' frames may differ from those of the researcher and from each other, and how insensitivity to such differences could cause researchers to miss or to misread important data, lose the subtle nuances of ways in which risk perceptions and understandings may be played out, or fail to generate a sufficiently rich picture of risk in people's everyday life experiences. By drawing attention to the ways in which the multiplicities of framing and their possible incongruities are negotiated by involved parties, a reflexive analysis is presented in 
the sense of putting our own assumptions and interpretive practices as researchers into the analytical frame of the research itself (see e.g. Brannen and Edwards, 1998).

Framing of risk is considered at three stages of the research process - constructing research topic, introducing the research to participants, and interpreting meanings of data. A comparative approach is taken reflecting on the methodological work involved in three qualitative interview-based research projects, each investigating rather different types of risk situation. Despite their differences all three projects focussed on 'everyday life' settings and shared certain theoretical and methodological assumptions, which might best be described as a contextual or situated view of risk, but all set within a broader sociocultural perspective.

The paper commences with a brief conceptual discussion of framing in relation to sociocultural risk research, followed by descriptions of each of the three empirical projects to be drawn upon in the comparative discussion.

\section{Risk, framing and sociocultural research}

A first step in our consideration of ideas of risk and framing is to acknowledge that just as there are differences in the conceptualisation of risk, so there are different perspectives on individuals' responses to risk. Researchers deploy the concept of risk when examining everyday situations involving 'decision' and 'choice', but these situations are regarded differently from different theoretical perspectives. Theorists adopting a rational actor or economic perspective tend to view individuals as making (objectively) rational choices to minimise risks. However this approach has been 
criticised for its overly cognitive and rationalistic account of human preferences and behaviour, and their interrelationship with social norms (see Jaeger et al 2001; Lowenstein et al, 2001).

One finds a somewhat different emphasis on individual choice in the work of Beck and Giddens and of others who draw on their theories of the 'risk society' or 'late modernity'. These maintain that not only has risk become a defining feature of society but that, with the erosion of universal social norms, individual choice is experienced as having an increasingly central role in dealing with risk as people's lives become reflexive projects (Beck 1992; Beck and Beck-Gernsheim 1995; Beck-Gernsheim 2002; Giddens 1992). Yet this perspective has been criticised too, for continuing to place too great an emphasis on cognitive processes as drivers of behavioural response (Lash 1994).

In contrast to both of these (rational actor and risk society) perspectives, it is possible to adopt an approach that pays far greater heed to the immediate (local, situated) social and cultural contexts in which decisions are made, and the ways in which these shape or may even appear to preclude choice, at least from the point of view of the individual. Such a sociocultural perspective also deals explicitly with perceptions of risk, and a shared assumption of all three projects discussed in this paper is that biography and people's everyday lives are key resources for understanding how those perceptions come into being and are played out. More specifically, a person's biographical background and the contexts in which their everyday lives are lived out are important factors that may shape their subjective 'risk positions'; that is, their 
relationship to sources of risk, their perception of risk and the strategies that may or may not be available to them for coping with risk.

Of course, individual perceptions of and responses to situations encountered in everyday life are permeated too by context and culture in ways that involve the operation of wider sociocultural discourses. Such discourses are constitutive of everyday meanings and hence, in turn, affect the way any particular situation can be perceived or 'framed'. Sociocultural framings of risks and risk discourses operate at both macro- (e.g. institutional) and micro- (situational) levels. Macro-level analyses of sociocultural framing utilise various perspectives on risk governance processes (see e.g. Lupton, 1999; Dean,1998; Rose, 2001; also Walls et al, 2005) and provide insights into broader issues encountered by risk researchers who seek to understand risk's institutional standing, its cultural and organisational pervasiveness and its regulatory power. At times, however, this work questions the macro-micro boundary, and examines how such regulatory processes are able to gain some purchase on people's culturally inflected, everyday forms of risk awareness, understanding and subjectivity (Tulloch and Lupton, 2003; Hollway and Jefferson, 1997).

The particular form of micro-analysis of people's situated sociocultural understandings and framings of risk adopted by all of the projects discussed in this article is similarly concerned with the operation of broader sociocultural discourses of risk and related matters (uncertainty, danger, threat etc), but with a focus on investigating if and how risk discourses and meanings work in the context of people's practical sense-making about the world. In common with the longstanding tradition of situational analyses, we are typically interested in how frames of reference or 
'schemata of interpretation' allow individuals "to locate, perceive, identify, and label" events in their own terms (Goffman, 1974, p. 21). Such interpretative schemata are viewed not merely as individual artefacts, but as deriving from the social and cultural context pertinent to that event or situation and therefore are likely to be shared, to varying degrees, with others. This latter idea is captured by another definition that usefully elaborates on the constitutive elements of frames, referring to them as "the perceptual lenses, worldviews or underlying assumptions that guide communal interpretation and definition of particular issues" (Miller, 2000: 212). An individual's practical understanding of and response to a situation or event will therefore be shaped by the specific frame of reference within which they situate it, an act which may reflect their own particular motivations and criteria of relevance but which will in turn draw from or reflect assumptions and discourses available within their sociocultural context, including the framing of issues by powerful institutions, or in the mass media (Reese et al, 2003; Kitzinger, 2007).

When we examine risk situations in terms of framing processes, however, we encounter an additional level of complexity. This may be illustrated if we first consider a very simple example of framing: in one context a plant may be defined as a 'wild flower' but in another context, where it is defined according to cultural norms and practices as being in the wrong place, that same plant is viewed as a 'weed'. If, however, 'risk' is substituted for the plant in this example there is a danger of reifying risk; that is, treating it as a thing to be framed. Instead, from a sociocultural perspective, there is a need to see risk both as a constructed, if sometimes conventionalised, quality or potentiality of an object or situation and as one frame among many through which that object or situation might be perceived and 
understood. Perceptions of the 'riskiness' of a situation will therefore depend on the interactions among context and culture, individual biography and a variety of available frames, several of which may be competing at any given time. Furthermore, people may shift frames, that is reframe a situation in different terms, as the (discursive) context changes. It is therefore perhaps not surprising, then, that in researching risk both the researcher and the research participant can frame situations in multiple and possibly different ways.

\section{Description of projects, methods and research interactions}

The three research projects investigated the risks associated with partnership and parenthood, employment, and living near a nuclear power station and are referred to hereafter as the Partnership project, the Employment project and the Nuclear project ${ }^{1}$.

The Partnership project used semi-structured interviews with forty-seven participants in different types of heterosexual partnerships. Semi-structured interviews were chosen as the best method, within the constraints of a one-off interview, for obtaining information on the topics that the researchers had identified as potentially important, while at the same time 'leaving space' for other issues to arise and be pursued. The sample was drawn from an Office for National Statistics' national Omnibus Survey. Interviews explored the perceived impact of partnership, partnership type and parenthood on participants' economic, social, and career standing, and on their sense of identity.

\footnotetext{
${ }^{1}$ This paper draws on the projects at an interim stage of their research.
} 
The Employment project used biographical interviews with twenty-nine adults and each of their same-sex parents. Sampling members of different generations within families enabled examination of intergenerational continuities and discontinuities in how participants perceived and responded to 'risks' associated with changing employment. At least one participant in each pair had left a job (either changed job or become unemployed) within the preceding two years, and the sample was mixed in terms of gender and socio-economic grouping. An analytical device used in the research was to explore critical moments in individuals' employment history. These became the foci for the interviews, which explored participants' decision-making in relation to these changes or, at least, their roles in the processes of change in their careers. This biographical approach led to consideration of career in a broad sense, intertwining job change with life change, and decision-making about jobs with reflections on personal agency over the life-course.

The Nuclear project used narrative interviews with thirty-two people living in villages near to the Bradwell-on-Sea nuclear power plant in Essex. Participants reflected a broad cross-section of the local community (ages, gender and length of residence locally), and also included a small number of people more actively engaged with the nuclear issue, either through active opposition or alternatively employment links with the plant. As a methodologically reflexive project it asked the question 'how useful might a narrative interview strategy be for eliciting data on people's experience of and responses to living in the vicinity of a major technological hazard?' Narrative style interviews were chosen in the belief that by being able to talk at length about a trajectory of lived experiences (that is to say, by communicating narratively) people might be able to express more fully the interrelationships between a number of factors 
- including biography, shared values, knowledge and relationship to place - which might influence their view of the potential risk (Satterfield, 2002). However, pilot interviews suggested that the power station might not feature as relevant within the place-based and life story narratives of some interviewees. Interviewees were also asked therefore for their views about the power station and about past events that had brought discussion of nuclear-related risk into the local public sphere. Hence, the nuclear study employed a hybrid interview strategy involving both narrative and semi-structured elements.

Table 1 outlines the conceptual and methodological dimensions to each of the three projects.

\section{[INSERT TABLE 1 ABOUT HERE]}

The remainder of the paper draws upon these projects for illustrations of the epistemological and methodological issues raised by risk framing, beginning with the ways in which risk framing is negotiated in the research process.

\section{Epistemology, risk framing and negotiated meanings in the research process}

As outlined in the introduction, a central concern of the paper is with the different framings that researcher and research participant produce in the research situation, specifically in qualitative interviews. While for the risk researcher those framings will be primarily in terms of some conceptualisation of risk, as already suggested, for the participant they may not. Even where a situation or event is mutually framed in terms 
of risk, there may be differences in how risk or related concepts are understood. What takes place in the interview, therefore, is not simply the 'collection of data' but a negotiation of framing that has important implications for the data that are produced and for how they are interpreted. This section of the paper will look at this process of negotiation first in relation to the admissibility of a risk framing and then to the significance of nuanced differences in the way in which such risk framings are constructed.

Constructing the fieldwork encounter: the admissibility of risk framing?

A key epistemological issue for the researchers, although not to the same degree in each project, was whether introducing the notion of risk to participants, either at the recruitment or interview stage of research, would thereby impose a framing that would produce self-confirming data. All three projects had been concerned to interrogate the claim made by risk society theorists that risk awareness and evaluation has become a defining feature of everyday life (for a critical overview of such claims see Mythen, 2004). The very nature of each of the projects demonstrates the belief that, in light of prevalent social conditions and discourses, certain events or states have marked potential to be perceived as 'risky' by participants. The researchers were, of course, aware that not all participants would share this frame and that they might operate with different 'definitions of the situation' ( $c f$. Simmons 2003).

The Partnership and Employment projects had started their fieldwork with the view that to mention risk explicitly to participants might impose a particular frame of reference that could influence the responses given. The researchers were wary not 
only of 'reading something into' the data, but of actually creating a perception that would not 'naturally' have occurred to the participant. The Nuclear project differed somewhat from the other two in that its focus of study had traditionally been framed in terms of danger, both in the UK and in many other intensively industrialised countries (and indeed is a one of the prototypical threats of modernity discussed by Beck in his risk society work $)^{2}$. Accordingly, when participants were first introduced to the project, and in the information sheets they were given, they were told explicitly of its purpose: to investigate people's everyday experiences of living with technological risk. Subsequently, in the interviews, participants were asked how they felt about living near to a nuclear power station. This presented a relatively explicit risk framing, one which, it is reasonable to assume, would be transparent to most if not all potential participants given that it is the potential dangers of nuclear facilities that typically make them a focus of interest. In effect the Nuclear project's 'object of inquiry' was presented to participants as being associated with potential risk from the outset.

Nonetheless, the Nuclear project did share the other projects' epistemological concerns about overly constraining or even artificially generating the narrative focus for participants, and hence was cautious about the overt use of the terminology of 'risk' in the interviews. In the event the term 'risk' itself was not used a great deal, and sometimes not at all, by interviewer or interviewee, although euphemisms and

\footnotetext{
${ }^{2}$ Of course, this popular representation of nuclear power as a global catastrophic 'threat' is no longer universal, either in some developing nations (where it can still represent an icon of high technology and 'progress', as well as a route to both political and military power), or in some contemporary Western policy discourses which link nuclear energy with attempts to combat global climate change and future energy shortages (see Pidgeon, Lorenzoni and Poortinga, 2008).
} 
synonyms such as 'danger' and 'threat', as well as more oblique references to risk expressed for example as 'concern', did appear instead. Where risk was not raised spontaneously as an issue within a participant's narrative, they were asked, later in the interview, if it was something they thought about in their lives, and specifically in relation to the power station's presence in their locality. This approach allowed for differences between interviewees' narratives to emerge: some indeed constructed the power station as potentially hazardous or as posing an indeterminate level of risk, while others' narratives had the effect of minimising, normalising or disregarding any potential risks or concerns.

Over time, all three projects came to a more explicit use of the term risk. This enabled them to test the meaning and relevance of the term for participants, to encourage participants to make their implied meanings more explicit, to stimulate a reaction or to legitimate an alternative account. A thorough test of the effects of this was carried out by the Employment project, which re-interviewed eleven participants, asking them explicitly about risk in order to test whether focusing on the term had any impact on how they reflected on their careers and decision-making. Only one participant responded to the term, re-telling her career as a process of negotiating risk, though notably she indicated an occupational familiarity with risk discourse and practice when she emphasised that her job included writing risk assessments. The other participants either rejected the relevance of risk as a concept in their lives or 'went along with' the researcher in reflecting upon the place of risk in the critical moments of their careers. Even after offering apparently compliant critical self-analysis of their career risks, participants tended to remain detached from the risk framing. One participant, for example, suggested that risk was too 'dramatic' a term to describe 
how he had approached thinking about career change. Another felt that, by thinking about careers in terms of risk, he and the researcher were 'trying to manipulate the word risk to fit that particular event'.

Despite initial concerns over imposing a risk frame, there was very little discernible evidence to suggest that referring explicitly to 'risk' significantly affected the way in which participants perceived the issue being discussed. As noted earlier, multiple framings of situations are always available and individuals are likely to have encountered and possibly rejected some of those alternatives prior to the encounter with the researcher. It is perhaps not surprising then that participants did not seem to perceive the use of the term risk as imposing an illegitimate or inappropriate agenda on them - even if their own narratives worked to downplay the importance of risk and in the one or two instances where they did, they were prepared to challenge the researcher's framing. These findings, supported by the experience of all three research teams, suggest that referring explicitly to risk in this type of research may have minimal impact on participants' preparedness to express their own framings and responses.

However, the fact that participants were able simultaneously to resist the concept of risk and to offer self-analysis of risk may raise other questions. For example, what significance should be attached to the way that individuals are able to produce a discursive performance within the researcher's framing without necessarily 'buying into' that framing? As in all research it is difficult to disentangle lived reality from the presentation of that reality. The performances that Goffman calls individuals' public 'presentation of self' are found just as much in the research encounter as in other 
forms of social encounter, even in highly structured encounters like the questionnaire survey (Eliasoph, 1990). Researching the concept of risk, however, is perhaps subject to particular problems in this respect (Smith et al, 2006). Disregarding for the moment whether or not people actually think in terms of risk in the areas of everyday life under research, risk discourse is more naturalised and even constitutive of collective representations or self-identity in certain aspects of life. So when talking about investments, gambling or speeding people will naturally and unselfconsciously think and talk in terms of risk or of 'taking a chance'. Similarly, in relation to what are perceived as imposed threats, such as contamination events, many people will talk in terms of risk, although not necessarily in the calculative way that would be recognised by rational actor theory or by risk assessment professionals. In areas of experience where other discourses are dominant people may not talk in terms of risk even if they on some level think in these terms. For example, in the Partnership project's earlier interviews in which the term 'risk' was not used, it appeared that few people presented themselves as thinking about intimate relationships in terms of risk. However, even when people did talk about these sorts of life situations in such terms, the risk was distanced from their own situation. So 'marriage' could be presented as risky, but 'my marriage' was not. During the course of the fieldwork the researchers felt that, given the prevalent discourses on romantic love, there was perhaps more advantage in 'allowing' people to present themselves as thinking in terms of risk by introducing the term than there was danger of distorting people's risk-awareness and responses.

Interviews inevitably involve a process of co-construction of narratives. This may be tacit or more explicit. For example, Griffin (2007), arguing against the traditional call 
for researchers' to be 'invisible' in the research interview, celebrates the active presence of the researcher:

"this allows for the possibility of a meeting between the perspectives and agendas of the interviewer (and hence of the assumptions around which the research process is constructed), and those of the interviewees. The analytic process would ideally aim to reflect and focus on those points at which the perspectives of interviewers and interviewees interact." (Griffin 2007, p.261)

Griffin's idea of perspectives 'meeting' and 'interacting' throughout the interview process resonates with key aspects of the approach taken in each of the projects discussed here. While all three projects maintained that it was a key priority not to obscure the contextual frames and orienting concerns of their interviewees, to a greater or lesser degree they also actively invited participants to consider how an aspect of their lives could be construed in terms of risk. For each of the three areas studied there is an associated 'objective risk' discourse, whether about divorce and partnership breakdown rates, employment insecurity and career uncertainty, or nuclear safety and epidemiological assessment of radiation health risk. All of these discourses are present in the cultural milieu in which these individuals exist and are accessible as framing resources. Conclusions drawn from each of the projects therefore attach considerable importance to the way that most participants produced accounts about how they routinely lived their lives, which made no reference to - or even seemed actively to exclude - relevant risk frames. 
All of the projects took an event-focussed approach. This largely reflected practical constraints that precluded an extended ethnographic approach to data collection or even unstructured interviews that simply allowed people to talk unprompted about 'living in the area' or their relationship or career history. However, as with the introduction of a risk framing by the interviewer, there is the possibility that this selection of focal events framed the narratives produced in ways that reflected the viewpoint of the researcher rather than the subjective experience of the interviewee. In this respect there was some difference in approach between the projects. The events explored for the Nuclear project were public events that had provoked local reactions and therefore held potential personal and community relevance for those living near to the nuclear power station. These events included: the local public inquiry held prior to constructing the station; the Chernobyl accident; proposals and protests regarding nuclear waste developments at or near the site; and the publication of a report claiming higher than expected levels of breast cancer in the area and the subsequent official rebuttal, all of which received local media coverage. Not all interviewees were willing to adopt these events as a narrative focus and some passed quickly over them to return to other concerns that formed part of their own story. In the Employment and Partnership projects the events raised in the interviews were 'personal' - changing jobs, getting married, having children, separating or getting divorced. Furthermore, in order to avoid imposing a definition of 'critical moments', participants in the Employment project were invited to 'map out' their employment/life history and asked to identify what they felt had been key moments in their careers. In all three projects it may reasonably therefore be assumed that the view of these events as being significant was common both to the researcher and the participant, although of course the reasons for the significance could still differ. 
Constructing accounts, constructing frames: analytical challenges of variability in framing risk meanings.

Up to this point the focus has been on the potential for mismatch between the researcher's framing of a situation or event in terms of risk and the extent to which this might constrain or shape the adoption of alternative framings (ones that do not foreground notions of risk) by research participants in the fieldwork setting. This consideration applies with even more force at the analytic stages of any qualitativelyoriented risk project. The research for all three projects highlighted the complex and multi-layered ways in which risk was constructed in individuals' accounts of their lived experience and, even when focused on life experiences that were widely shared, the diversity of individual responses. Accordingly, at the data analysis stages it was clear that applying an analytical risk framing constructed solely in terms of choices, decisions and individual agency could obscure alternative framings. Frames are constructed not only around 'facts' but also signs, symbols and metaphors (Schön and Rein, 1994; Irwin, Simmons and Walker, 1999; Flynn, Slovic and Kunreuther, 2001; Pidgeon, Kasperson and Slovic, 2003). For example, previous research has highlighted the range of different understandings of marriage that people can adopt (Lewis 2001). In the Partnership project a few of the participants viewed marriage through a 'sacramental' frame. Marriage for them was imbued with symbolism and meaning that was quite separate from discourses of, for instance, legal protection or social status. This means that the researcher has to be particularly sensitive to nuanced understandings and usages on the part of participants. While the need to both respect and reflect participant (emic) understandings is not a particularly new issue for 
qualitative social sciences research more generally (see e.g. Lincoln and Guba, 1985; Bryman, 1988; Henwood and Pidgeon, 1992), it has received less discussion in the social science risk arena, most probably because of the latter's tradition of quantitative empirical enquiry, and a concern to interrogate any such descriptive analysis against normative considerations.

As noted in the introduction, rational actor perspectives on risk tend to accord individuals with agency in making more or less 'rational' (i.e. normatively coherent and correct) choices about risks. In each of the current projects, individual agency could be constrained within very different frameworks applied to situations acknowledged to be 'risky' For instance, constraints upon agency could be presented at times within a fatalistic framing, perhaps most evident in the Nuclear project, where some participants made references to the power of vested interests and their distrust of those who managed the risks, or to the impossibility, in a post-Chernobyl world, of moving to anywhere that would be safe were a major accident to occur. Equally, most participants in the Employment project rejected the notion that they 'life planned' in the way that Giddens (1991) presents it, and instead talked of events “just happening”. This may be interpreted as reflecting a worldview in which the individual has little agency or, as has been suggested elsewhere, as a form of impression management that served to distance them from the risk of making a wrong decision and therefore from responsibility for 'failure' (Smith et al 2006). In the Partnership project, by contrast - where implicitly normative terms such as "the next step" or "the right time" and, perhaps most revealingly, "a natural progression" (a theme which also appears in the employment project) were used repeatedly by 
interviewees - the de-emphasis of agency could be construed as the enactment of a particular socio-ethical ordering.

An alternative risk framing, in which personal agency was constructed in terms of 'taking a chance', was also evident in the Employment and Partnership projects. Rather than being viewed passively or having negative connotations, choice and risk were associated with the opportunity to gain something that was desired, albeit with the possibility that in striving for a desired goal things may also 'go wrong' ( $c f$. Machlis and Rosa,1990). The notion of romantic love is inherently unstable yet the vast majority of respondents in the Partnership project framed their relationship in terms of the opportunity for personal happiness, despite acknowledged uncertainty (Lewis 2006). A similar framing emerged at times in the Nuclear project interviews with people choosing to live in the area because they valued its landscape and amenities (access to the sea and seashore, unspoilt country etc.), despite occasionally acknowledged awareness of putative dangers associated with the nuclear power station. For a few of these individuals the risk from the station was even transformed, from something singularly negative to something far more multilayered. From their perspective the potentially stigmatising risk frame imposed on the communities closest to the power station delivered indirect benefits; for example, by helping to stave off the possibility of rural overdevelopment and the loss of amenity and increase in (other) everyday risks such as traffic accidents that might accompany further development. That is they viewed others' perception of an association between the nuclear power station and risk in their locality as partly instrumental in protecting a highly valued environment and way of life. In all three projects, however, this positive framing in terms of striving for valued goals in life and creating positive meanings 
and forms of intelligibility (in which risk-benefit trade-offs are implicit at best) could also be associated with discernible ambivalence arising from an awareness of both the positive and negative outcomes highlighted by such a framing, a nuance to which researchers need to be sensitive during both the research interview and data analysis.

Variability was evident not only in the construction of risk frames, but also in way in which such frames were applied within the broader narratives that people told about their lives. In the Nuclear project, some people did indeed mobilise the iconic image of Chernobyl, characterising the nuclear power station as a potentially catastrophic threat on a global scale, in order to frame their accounts (cf. Beck, 1992). Others used a risk framing to produce a health-focused narrative focusing on uncertainties about the evidence linking nuclear energy, radiation and the local incidence of cancer. This narrative revealed participants as experiencing low level worries, or actively suppressing such worries, about a technology they lived with every day and that might possibly turn out to be harmful. In contrast to both of these, others used a risk framing to tell a different story, one in which the stigmatisation of nuclear technology itself might endanger the security of future energy supplies at great social and economic cost to the nation. A similar variation in the way in which risk frames were applied can be found in the other projects; in the Employment project, for example, talk of dangers and uncertainty associated with careers was as much if not more about the risk of 'not making the best of one's life' as it was about economic uncertainty.

Taking account of social and cultural context 
When employing framing analysis to address the contextualisation of risk understandings and the associated dilemmas of how to deal with nuanced differences of meaning produced by researcher and researched in the research process, it is also important to take account of the different ways in which the social and cultural context features within the framings that are invoked. While qualitative research relies heavily on a research participant focus to gain a nuanced understanding of participants' worlds (an 'emic' frame) (Charmaz and Henwood 2007), it is both inevitable and desirable to work with an 'etic' frame consisting of one's own, more detached, theoretical constructions (for further discussion of these terms cf. Headland et al. 1990). Accordingly this section draws attention to a range of etic or theoretical considerations and constructs we find useful for further situating our analysis of risk framing and perceptions in varied everyday life situations, and which point towards some key, potentially explanatory, contextualising frameworks.

Underpinning the various constructions of uncertainty, danger and benefit, there is often a dynamic relationship between risk framing and social and cultural networks. Risk positions are not only defined by such networks, but also help to create people's self-identity as part of a group or subculture (Douglas and Wildavsky, 1982; Macgill 1989). For instance, while those who cohabit may forgo a degree of legal protection, the 'edge' associated with being outside the institution of marriage may be a desired state (Lyng, 2008). In the Partnership project people differed in their orientation towards the established way of doing things. Just as one married respondent said she felt "comfortable and safe with this type of relationship, in a traditional way" and another identified himself as part of "the husband and wife club", so non-married people could identify themselves as living an alternative lifestyle. Equally, where 
people self-identify as having a strong attachment to their locality, as with many interviewed for the Nuclear project, they may resist frames, particularly when used by outsiders, which present their environment in threatening or stigmatising terms, while at the same time acknowledging the potential source of that stigma ( $c f$. Simmons and Walker, 2004).

In this respect social values (e.g. beliefs about relationships and the value of marriage, about employment and the meaning of work, or about environmental protection and the value of place) become an important influence on how and when people employ risk frames in their biographical narratives, for example in relation to desired ways of life. In the Nuclear project, participants' discourses were not necessarily of 'life planning' but often rooted in the connections - physical, social and psychological built up over time between person and place, as well as wider relationships of trust (or alternatively distrust) with institutional authorities. Under such circumstances, as noted above, individual agency was presented as being circumscribed by countervailing forces and constraints, while people's constructions of risk in these circumstances drew upon their own situated knowledge of the world, based on their contextual and typically shared experience both of place and institutions ( $c f$. Wynne 1996; Irwin, Simmons and Walker 1999). On occasions, the result could be a heady mix of highly emotive risk perceptions, based in complex resentments and frustrations over the dynamics of dependency and protection between local communities and regulatory bodies (Henwood, 2008).

Social and cultural diversity, as it impacts upon people's values, risk positions and identities, was also central to understanding participants' perspectives in the 
Employment project. Social class and gender mediated participants' reflections on their careers, but so did the temporal dimension of changing values over time. For example, for the parent generation, their biographical narratives were framed in terms of community and family life and of social aspirations expressed by phrases such as "earning your way" and "not being a burden on society"” For the offspring generation, there was a greater emphasis on "finding your own way in the world" and taking responsibility for constructing your own career or individualised biography in a way that exemplified Giddens's (1991) account of the reflexive life project which was noted above. Difference here reflects, in part at least, a generational difference produced by the neo-liberal transformation of the labour landscape, one marked by a shift from expectations of the 'job for life' as a collective experience to an expectation that work means individually negotiating a series of volatile and contingent jobs and framed by discourses of flexibility and individual responsibility.

Unsurprisingly, as well as these structural and cultural factors, biographical context was also an important factor. The Partnership project found that people's framing of different relationship types and the risks they associated with them was influenced by past failed relationships or the presence of children (Lewis 2006; Haskey and Lewis 2006). People's networks can play important roles in the social construction of risk perceptions, and through this affect the degree to which people feel able to avoid perceived risks. Relationships of interdependence can magnify perceived risk through a knock-on effect, or diffuse the impact of perceived risk ( $c f$. Lupton and Tulloch 2002). In the Partnership project this was clearly evident. Decisions within, as well as about, intimate relationships can affect parties to different degrees. Parties to a relationship may also have different 'risk toleration thresholds', in that they may be 
more or less amenable to taking risks or living with uncertainty. This has two implications for risk researchers. Firstly, from a social context perspective, it is important that researchers be sensitive to the ways in which people's network of interdependencies may frame and influence the ways in which they think and act: an asocial portrait may be a distorted depiction of individual experience. Secondly, it is important to recognise that 'decision-making' may be processual rather than a single moment, so that the researcher may only understand the influences on and the effects of (explicit or implicit) 'decisions' in the long-term: in other words, a diachronic perspective may be needed to capture what may be missed - or misinterpreted - by a synchronic 'snapshot'.

To summarise, this section of the paper has outlined some of the theoretical resources deriving from etic frameworks available to the sociocultural researcher studying risk and everyday experience to illustrate some of the further complexities encountered when negotiating the application and meaning of a risk framing in relation to relevant aspects of an individual's life. Some of the specific epistemological, and practical methodological issues raised here and in previous sections are revisited in the concluding discussion.

\section{Conclusions}

This paper, drawing upon a sustained comparative reflection upon three different research projects, has explored the epistemological and methodological implications that may arise from the different ways in which 'risk' is framed, both by researchers and by research participants, during the research process. An advantage of this 
innovative and ambitious comparative approach is that this has allowed us to identify a range of important considerations for research that seeks to investigate risk issues in everyday settings and as they intersect with people's biographies and lives.

We have considered how there may be a tension between not imposing the researcher's framing on interviewees while nonetheless considering from an analytical perspective the ways in which people's everyday lives may be imbued with risk. Each of the research projects have dealt with this tension in somewhat different ways but, in order to proceed sensitively in their research on this issue, all three projects saw the question of how to utilise the term 'risk' and associated terms in the interviews as a key methodological concern. Having reflected on our own practices, we would conclude that use can be made of the term risk by researchers when generating data from interviews in at least three ways. Firstly, making explicit reference to risk can help to open up an exploration of its meaning(s) for participants. Secondly, it can create a climate in which a discourse of risk is available and legitimate for participants to use in their accounts when this might otherwise not be felt by them to be the case. Thirdly, it can prompt interviewees to make tacit meanings more explicit and to voice their reactions to issues about which they might otherwise have remained silent, whether unwittingly or because it was deemed inappropriate for some reason.

We have suggested that the risk researcher also needs to take account of the relative prominence of risk discourse in different domains of life. When other discourses define the way that a particular domain of practice is conceived, so that this view becomes the taken for granted or 'common sense' perspective and dominates or 
weakens risk discourses, people may in effect be 'disallowed' from speaking within a risk frame. In such instances, the extent to which they can express or suppress risk awareness is limited or even silenced. When, on the other hand, the domain being studied is one in which risk discourse has a more constitutive or at least more overt role, the methodological challenge is more to elicit the variety of risk frames that can be brought to bear from people taking into account their biographical differences and range of social and cultural positionings. These may not become available if studied in ways that are either overly directive or overly non-directive, as in both cases dominant risk discourses may shape the course of data collection and preclude the more subtle negotiations between different biographical and sociocultural frames.

One of the projects under discussion, the Nuclear project, set out to consider the potential of using a narrative method of eliciting people's understandings of risk and subject positions in relation to risk issues, and to promote sensitivity on the part of researchers to the need for more subtle negotiations between different risk frames. A methodological finding from this project is that this can result in the creation of a more fragmented set of risk stories involving both the take up of dominant discourses and commentary upon them, and alternative frameworks linked to a range of values, identities and ways of life. But there remains a challenge for the narrative risk researcher - to find ways to stimulate relevant narration. People can be adept narrators in terms of telling their own stories, passing over researcher directed questions when these are irrelevant to their own concerns. It cannot therefore simply be assumed that all participants' stories of life, community and place will treat the risk issue being studied as a focal aspect of their experiential worlds. Participants may be detached from and resilient to researchers' frames, even when their awareness is raised in ways 
that fall outside of everyday experience. Equally, however, we cannot assume that participants will be unaffected by the different assumptions that are revealed when new concepts of risk are introduced, particularly those which imply harm to people or which threaten constructs that protect their sense of ontological security (Pidgeon, Simmons, Sarre, Henwood and Smith, forthcoming). Thus, there is considerable methodological challenge for researchers as they seek to find ways to negotiate these tensions between participants' stories and their own theoretical and substantive concerns. That said, it is important to recognise that such differences are not simply a problem but an opportunity. Accordingly, all three research teams concur with Griffin (2007) that it is important to focus analytically on those occasions when participants' and researchers' framings differ for the insights that these moments can afford.

While there are no doubt different ways of confronting the dilemmas posed to researchers by issues of framing, in this article we have mainly discussed two. One is to be sensitive to the multiplicity and variability of frames and to the often unacknowledged process of negotiating different and contested frames. A second is to acknowledge that participants routinely live their lives with no reference to risk at all. However, the challenges that this presents to the researcher are not ones that we have been able readily to resolve in this paper; in fact, they may reflect an inherent epistemological instability in a position that tries simultaneously to respect rather than merely record the perspectives of research participants and to set their lives and their experience within an analytical perspective framed in terms of risk. Cultivating an awareness of these issues and the dilemmas that they pose is, we would maintain, a necessary first step. It may not be possible to work through these issues to a 
resolution, but it is at least possible to work with them in a reflective and constructive way. 


\section{References}

Beck, U. (1991) Modernity and Self Identity: Self and Society in the Late Modern Age (Oxford, Polity)

Beck, U. (1992) Risk Society: Towards a New Modernity (London, Sage)

Beck, U. and Beck-Gernsheim, E. (1995) The Normal Chaos of Love (Oxford, Polity)

Beck-Gernsheim, E. (2002) Reinventing the Family: In Search of New Lifestyles (Cambridge, Polity)

Brannen, J. and Edwards, R. (1998) Editorial. International Journal of Social Research Methodology: Theory and Practice. 1(1), pp. 1-6.

Bryman. A. (1988) Quantity and Quality in Social Research. London: Unwin Hyman.

Charmaz, K. and Henwood, K. (2007) 'Grounded Theory' in Willig, C. and StaintonRogers, W. (Eds.) Handbook of Qualitative Research in Psychology London: Sage.

Dean, M. (1998) Risk, calculable and incalculable, Soziale Welt 49(1), pp. 25-42. 
Douglas, M. and Wildavsky, A. (1982) Risk and Culture: The Selection of

Technological and Environmental Dangers (Berkley, University of California Press).

Eliasoph, N. (1990) Political-culture and the presentation of a political self: A study of the public sphere in the spirit of Erving Goffman, Theory and Society, 19, pp. 465-494.

Flynn, J, Slovic, P. and Kunreuther, H. (2001) Risk, Media and Stigma (London, Earthscan)

Giddens, A. (1990) The Consequences of Modernity (Cambridge, Polity)

Giddens, A. (1991) Modernity and self-identity: self and society in the late modern age (Cambridge, Polity Press)

Giddens, A. (1992) The Transformation of Intimacy: Sexuality, Love and Eroticism in Modern Societies (Cambridge, Polity)

Goffman, E. (1974) Frame Analysis (New York: Harper)

Griffin, C. (2007) "Being dead and being there: Research interviews, sharing hand cream and the preference for analysing "naturally occurring data"' Discourse Studies, 92, pp. 246-269 
Hammersley, M. and Atkinson, P. (1983) Ethnography: Principles in Practice

(London, Routledge)

Haskey, J. and Lewis, J. (2006) 'Living-apart-together in Britain: context and meaning'. International Journal of Law in Context 2(1), pp. 37-48.

Headland, T.N., Pike, K. L., Harris, M. (Eds) (1990) Emics and Etics: The Insider/Outsider Debate. Newbury Park, CA: Sage Publications.

Henwood, K.L. (2008) Qualitative research, reflexivity and living with risk: valuing and practicing epistemic reflexivity and centring marginality. Qualitative Research in Psychology, 5(1), pp.45-55.

Henwood, K.L. and Pidgeon, N.F. (1992). Qualitative research and psychological theorizing. The British Journal of Psychology, 83, pp. 97-111.

Hollway, W. and Jefferson, T. (1997) The risk society in an age of anxiety: situating fear of crime. British Journal of Sociology, 48(2), pp. 255-266.

Irwin, A., Simmons, P. \& Walker, G., (1999) Faulty environments and risk reasoning: the local understanding of industrial hazards. Environment and Planning A, 31, pp. $1311-26$.

Janis, I.L. ands Mann, L. (1977) Decision Making: A Psychological Analysis of Conflict, Choice and Commitment. (New York, Free Press) 
Jaeger, C.C, Renn, O., Rosa, E.A. and Webler, T. (2001) Risk, Uncertainty and

Rational Action. (London, Earthscan)

Kitzinger, J. (2007) Framing and frame analysis, in: E. Devereux, Media Studies:

Key issues and debates (London, Sage)

Lash, S. (1994) Reflexivity and its doubles: structure, aesthetics, community, in:

Beck, U., Giddens, A. and Lash, S. (1994) Reflexive Modernization: Politics, Tradition and Aesthetics in the Modern Social Order (Cambridge, Polity)

Lewis, J. with Datta, J. and Sarre, S. (1999) Individualism and Commitment in

Marriage and Cohabitation Research Series no.8/99 (London, Lord Chancellor's

Department)

Lewis, J. (2001) The End of Marriage? Individualism and Intimate Relations

(Cheltenham, Edward Elgar)

Lewis, J. (2006) Perceptions of risk in intimate relationships. Journal of Social

Policy 35, pp. 39-57

Lincoln, Y S., \& Guba, E. G. (1985). Naturalistic Inquiry (Newbury Park, Sage).

Lowenstein,G.F., Weber, E.U., Hsee, C.K. and Welch, N. (2001) Risk as feelings,

Psychological Bulletin, 127, pp. 267-286 
Lupton, D. (1999) Risk (London, Routledge)

Lupton, D. and Tulloch, J. (2002) “Risk is Part of your Life': Risk Epistemologies among a Group of Australians' in Sociology 36(2): 317-334

Lyng, S. (2008) Edgework, risk and uncertainty, in: J. Zinn (Ed) Social Theories of Risk and Uncertainty (Oxford, Blackwell)

Macgill, S. (1989) Risk perception and the public: insights from research around Sellafield, in: J. BROWN (Ed) Environmental Threats: Perception, Analysis and Management pp. 48-66 (London, Belhaven)

Machlis, G.E and Rosa, E.A. (1990) Desired risk: broadening the social amplification of risk framework, Risk Analysis, 10, pp. 161-168

Miller, C. (2000) The dynamics of framing environmental values and policy: four models of societal processes, Environmental Values 9, pp. 211-33

Murphy, E., Dingwall, R., Greatbatch, D., Parker, S., Watson, P. (1998) Qualitative research methods in health technology assessment: a review of the literature, Health Technology Assessment 2(16), pp. 1-274.

Mythen, G. (2004) Ulrich Beck: A Critical Introduction to the Risk Society (London, Pluto Press) 
Mythen, G. AND Walklate, S. (Eds) (2006) Beyond the Risk Society: Critical

Reflections on Risk and Human Security (Maidenhead, Open University Press)

Pidgeon, N.F. and Gregory, R. (2004) Judgment, decision making and public policy, in: D. KOEHLER and N. HARVEY (eds.) Blackwell Handbook of Judgment and Decision Making. pp 604-623 (Oxford, Blackwell).

Pidgeon, N.F., Lorenzoni, I. and Poortinga, W. (2008) Climate change or nuclear power - no thanks! A quantitative study of public perceptions and risk framing in Britain. Global Environmental Change

Pidgeon, N.F., Kasperson, R.K. and Slovic, P. (Eds) (2003) The Social Amplification of Risk (Cambridge, Cambridge University Press)

Pidgeon, N.F., Hood, C., Jones, D., Turner, B.A. and Gibson, R. (1992) Risk perception, in: Risk - Analysis, Perception and Management pp. 89-134 (London, Royal Society).

Pidgeon, N., Simmons, P., Sarre, S., Henwood, K. and Smith, N. (forthcoming) The ethics of sociocultural risk research, Health, Risk and Society.

Reese, S. D., Gandy, O. H., Grant, A. E. (Eds) (2003) Framing Public Life:

Perspectives on media and our understanding of the social world (Mahwah, N.J., Erlbaum) 
ROSA, E.A. (2003) The logical structure of the social amplification of risk framework (SARF): Metatheoretical foundations and policy implications, in: Pidgeon, N.F., Kasperson, R.K. and Slovic, P. (Eds) (2003) The Social Amplification of Risk (Cambridge, Cambridge University Press)

Rose, N. (2001) The politics of life itself, Theory Culture \& Society 18(6): pp. 1-30.

Satterfield, T. (2002) The Anatomy of a Conflict: Identity, Knowledge, and Emotion in Old-Growth Forests (Vancouver, University of British Columbia Press).

Schön, D. and Rein, M. (1994) Frame Reflection: Toward the Resolution of Intractable Policy Controversies (New York, Basic Books).

Simmons, P. (2003) Performing safety in faulty environments, The Sociological Review 51 (s2) pp. 78-93.

Simmons, P. and Walker, G. (2004) Living with technological risk: industrial encroachment on sense of place, in: Å. Boholm and R. Löfstedt (Eds) Facility Siting: Risk, Power and Identity in Land-use Planning pp. 90-106 (London: Earthscan).

Smith, N., Cebulla, A., Cox, L. \& Davies, A. (2006) Risk perception and the presentation of self: Reflections from fieldwork on risk, Forum: Qualitative Social Research, 7, 1, Art. 9 
Taylor-Gooby, P. and Zinn, J. (Eds) (2006) Risk in Social Sciences (Oxford, Oxford University Press)

Tulloch, J. and Lupton, D. (2003) Risk and Everyday Life (London, Sage)

Walls, J., O’Riordan, T., Horlick-Jones, T. and Niewőhner, J. (2005) The metagovernance of risk and new technologies: GM crops and mobile telephones. Journal of Risk Research, 8, pp. 635-661.

Wynne, B. (1996) May the sheep safely graze? A reflexive view of the expert-lay knowledge divide, in: S. Lash, B. Szerszinsky and B. Wynne (Eds.) Risk, Environment, Modernity, pp 44-83 (London, Sage) 
Table 1: Summary of projects

\begin{tabular}{|c|c|c|c|}
\hline Projects & Partnership Project & $\begin{array}{l}\text { Employment } \\
\text { Project }\end{array}$ & Nuclear Project \\
\hline $\begin{array}{l}\text { Research } \\
\text { Topic }\end{array}$ & $\begin{array}{l}\text { The impact of partnership, } \\
\text { partnership type and } \\
\text { parenthood on economic, } \\
\text { social, and career standing, } \\
\text { and on identity. }\end{array}$ & $\begin{array}{l}\text { Employment change } \\
\text { including redundancy and } \\
\text { unemployment. }\end{array}$ & $\begin{array}{l}\text { Living in close proximity to } \\
\text { a nuclear power plant. }\end{array}$ \\
\hline $\begin{array}{l}\text { Researchers' } \\
\text { Framing of } \\
\text { 'Risk' }\end{array}$ & $\begin{array}{l}\text { Mostly chronic (i.e. long- } \\
\text { term) financial and legal } \\
\text { risks. }\end{array}$ & $\begin{array}{l}\text { Mostly chronic risks } \\
\text { associated with making the } \\
\text { 'wrong' career decisions: } \\
\text { e.g. poor job security / } \\
\text { satisfaction or career } \\
\text { development. }\end{array}$ & $\begin{array}{l}\text { Mostly an 'invisible' threat } \\
\text { with both chronic (e.g. } \\
\text { cancer) and acute (accident) } \\
\text { dimensions. }\end{array}$ \\
\hline Participants & $\begin{array}{l}47 \text { Heterosexual people in } \\
\text { intimate relationships. } \\
\text { - } 21 \text { married or cohabiting } \\
\text { people } \\
-14 \text { people in } 2^{\text {nd }} / \\
\text { subsequent co-residential } \\
\text { relationship } \\
\text { - } 12 \text { living apart together } \\
\text { people ( } 6 \text { of whom were } \\
\text { divorced). } \\
\text { All living in England, all } \\
\text { heterosexual. }\end{array}$ & $\begin{array}{l}58 \text { individuals interviewed } \\
\text { either as father and son or } \\
\text { mother and daughter pairs. } \\
\text { - Living between Yorkshire } \\
\text { and London, Cambridgeshire } \\
\text { and Wales; } \\
\text { Sampled to reflect a broad } \\
\text { cross-section of community. }\end{array}$ & $\begin{array}{l}32 \text { people living around the } \\
\text { Bradwell-on-Sea, } \\
\text { decommissioning nuclear } \\
\text { power station in Essex. } \\
\text { Sampled to represent a broad } \\
\text { cross section of the local } \\
\text { community (ages, gender } \\
\text { and length of residence } \\
\text { locally) } \\
\text { Interviews also included a } \\
\text { small number of people } \\
\text { engaged with the nuclear } \\
\text { issue, either through active } \\
\text { opposition or own/family } \\
\text { employment at the plant. }\end{array}$ \\
\hline $\begin{array}{l}\text { Starting } \\
\text { Assumptions }\end{array}$ & $\begin{array}{l}\text { - That there is reduced social } \\
\text { pressure to follow a } \\
\text { prescribed path to marriage } \\
\text { and parenthood, and } \\
\text { therefore more choice, which } \\
\text { in turn engenders a sense of } \\
\text { personal responsibility to } \\
\text { manage risk. } \\
\text { - The framing of risk } \\
\text { involves 'situated } \\
\text { knowledges' - individual } \\
\text { experiences, assumptions, } \\
\text { habits, symbols and } \\
\text { meanings. }\end{array}$ & $\begin{array}{l}\text { - The risk society thesis } \\
\text { implies increasing risk } \\
\text { awareness and } \\
\text { individualisation. If so, we } \\
\text { might expect to see this } \\
\text { change played out in the } \\
\text { difference between } \\
\text { generations. } \\
\text { - The erosion of the 'job for } \\
\text { life' and transformation of } \\
\text { labour market means that } \\
\text { people are more likely to } \\
\text { have to actively negotiate } \\
\text { their careers, involving } \\
\text { decision-making and } \\
\text { managing unknown futures. }\end{array}$ & $\begin{array}{l}\text { - Nuclear energy is the proto- } \\
\text { typical 'risk society' hazard } \\
\text { as discussed by Beck - so } \\
\text { should raise particular } \\
\text { feelings of vulnerability, } \\
\text { anxiety and catastrophe. } \\
\text { - People can and do construct } \\
\text { risk biographies, which } \\
\text { express their anxieties and } \\
\text { fears. } \\
\text { - Risk subjectivities involve } \\
\text { values embedded in } \\
\text { worldviews and local context } \\
\text { / place. }\end{array}$ \\
\hline Fieldwork & Jan $04-$ Jan 05 & Jan 05 - June 05 & Aug 04 - January05 \\
\hline Method & $\begin{array}{l}\text { Semi-structured interview, } \\
\text { including some very open } \\
\text { questions. Also used } \\
\text { vignettes, and a } \\
\text { questionnaire on financial } \\
\text { and legal arrangements. }\end{array}$ & $\begin{array}{l}\text { Biographical face-to-face } \\
\text { interviews, based on constant } \\
\text { topic guide but with open } \\
\text { questions and exploration. }\end{array}$ & $\begin{array}{l}\text { Narrative interviews, with a } \\
\text { focus upon biography - but } \\
\text { semi-structured questions } \\
\text { also with open responses }\end{array}$ \\
\hline
\end{tabular}




\begin{tabular}{|c|c|c|c|}
\hline $\begin{array}{l}\text { Brief topic } \\
\text { guide }\end{array}$ & $\begin{array}{l}\text { - Networks } \\
\text { - History of the relationship } \\
\text { and risk perceptions around } \\
\text { key decisions. } \\
\text { - Parenthood plans or } \\
\text { experiences. } \\
\text { - Negotiation. } \\
\text { - Managing risk } \\
\text { - Vignettes on dependence } \\
\text { within a) marriage and b) } \\
\text { cohabitation. } \\
\text { - Questionnaire on financial } \\
\text { and legal arrangements. } \\
\text { - (2n round only) influence } \\
\text { of past relationship on } \\
\text { choices made this time. }\end{array}$ & $\begin{array}{l}\text { - Mapping career biography; } \\
\text { participant identified 'key } \\
\text { moments' which became foci } \\
\text { for interview. } \\
\text { - How decisions were made } \\
\text { and whether they were 'good } \\
\text { decisions'. } \\
\text { - Familial and institution } \\
\text { influences on decision, if } \\
\text { any. } \\
\text { - Security: trust in future } \\
\text { (anticipated safety of making } \\
\text { change) and preparedness to } \\
\text { manage problematic } \\
\text { outcomes. } \\
\text { - Life-Planning: choice, } \\
\text { control, responsibility in } \\
\text { relation to the future/ } \\
\text { projected self. } \\
\text { - Inter-generational } \\
\text { comparison and influences. }\end{array}$ & $\begin{array}{l}\text {-The nuclear plant and its } \\
\text { presence. } \\
\text { - Importance and value of } \\
\text { Bradwell as a place. } \\
\text { - Personal biographies of } \\
\text { place/ life. } \\
\text { - Concerns about nuclear } \\
\text { power ands its possible risks. } \\
\text { - Impacts of key moments in } \\
\text { the plant's history (such as } \\
\text { Chernobyl, waste } \\
\text { controversies). } \\
\text { - Discourses about nuclear } \\
\text { power and energy more } \\
\text { widely. }\end{array}$ \\
\hline $\begin{array}{l}\text { How was } \\
\text { risk handled } \\
\text { during the } \\
\text { interviews? }\end{array}$ & $\begin{array}{l}1^{\text {st }} \text { Round - Indirectly. } \\
\text { Questions framed in terms of } \\
\text { 'issues', 'concerns', } \\
\text { 'uncertainties', 'worries' } \\
\text { 'taking a chance'. } \\
2^{\text {nd }} \text { round = more explicit. } \\
\text { Used term 'risk' in } \\
\text { introduction. A few more } \\
\text { questions using term. }\end{array}$ & $\begin{array}{l}\text { The term 'risk' not } \\
\text { mentioned unless respondent } \\
\text { did, but interview topic guide } \\
\text { designed to address } \\
\text { participant as (autonomous) } \\
\text { decision-maker. }\end{array}$ & $\begin{array}{l}\text { Directly. As risk from the } \\
\text { plant. However, this could } \\
\text { manifest in a number of } \\
\text { ways - acute accident, } \\
\text { chronic environmental } \\
\text { pollution, cancer risk to } \\
\text { individuals / communities, } \\
\text { radioactive waste storage etc. }\end{array}$ \\
\hline $\begin{array}{l}\text { What do the } \\
\text { researchers } \\
\text { aim to elicit? }\end{array}$ & $\begin{array}{l}1 \text { Perceptions of risk per } \\
\text { relationship type. } \\
2 \text { Pathways to relationship } \\
\text { type. } \\
3 \text { Mechanics of } \\
\text { managing risk. } \\
4 \text { Influences on risk framing } \\
\text { (social, religious, } \\
\text { experiential). }\end{array}$ & $\begin{array}{l}1 \text { Detailed reflection on } \\
\text { changes in employment in } \\
\text { context of biographical } \\
\text { accounts of career, more } \\
\text { broadly. } \\
2 \text { Test extent of risk } \\
\text { awareness in career } \\
\text { planning. } \\
3 \text {. Influence of and } \\
\text { comparison with other } \\
\text { family member. }\end{array}$ & $\begin{array}{l}1 \text { Narrative accounts of } \\
\text { living with nuclear risks. } \\
2 \text { Implicit values } \\
3 \text { Affect (emotion) and } \\
\text { ambivalences about plant. } \\
4 \text { Impacts of local identity / } \\
\text { place on risk awareness and } \\
\text { acceptability. }\end{array}$ \\
\hline
\end{tabular}

